\title{
Visualising Holocaust child-survivors in Canada: from post-war humanitarian campaigns to national memory
}

DOI:

10.1080/14780038.2019.1658698

\section{Document Version}

Accepted author manuscript

Link to publication record in Manchester Research Explorer

\section{Citation for published version (APA):}

Burgard, A. (2019). Visualising Holocaust child-survivors in Canada: from post-war humanitarian campaigns to national memory. Cultural and Social History, 0, [0]. https://doi.org/10.1080/14780038.2019.1658698

\section{Published in:}

Cultural and Social History

\section{Citing this paper}

Please note that where the full-text provided on Manchester Research Explorer is the Author Accepted Manuscript or Proof version this may differ from the final Published version. If citing, it is advised that you check and use the publisher's definitive version.

\section{General rights}

Copyright and moral rights for the publications made accessible in the Research Explorer are retained by the authors and/or other copyright owners and it is a condition of accessing publications that users recognise and abide by the legal requirements associated with these rights.

\section{Takedown policy}

If you believe that this document breaches copyright please refer to the University of Manchester's Takedown Procedures [http://man.ac.uk/04Y6Bo] or contact uml.scholarlycommunications@manchester.ac.uk providing relevant details, so we can investigate your claim.

\section{OPEN ACCESS}




\section{Visualising Holocaust child-survivors in Canada: from post-war humanitarian campaigns to national memory.}

In the immediate aftermath of the Holocaust, Jewish children became symbols of both wartime atrocities and post-war renewal. ${ }^{1}$ Over 1 million children had perished in the Nazi genocide and the rehabilitation and resettlement of the few who survived were among the most crucial international humanitarian and political issues of the early post-war era. In the spring of 1947, the main Canadian Jewish organization, the Canadian Jewish Congress (CJC), was authorized by the Canadian federal government to select and bring to Canada 1,000 orphans. ${ }^{2}$ The authorization depended on the enforcement of strict guidelines. First, the CJC had to accept the full legal and financial responsibility of the future newcomers. Second, their resettlement would have to be exclusively based on foster-care and thus relied on the willingness of Canadian Jewish families to welcome the young survivors into their homes. Pressured by the success of the search and selection phase in Europe and the quick pace of the orphans' arrivals in Canada, the CJC had to urgently set up an intense campaign to raise donations and find potential foster parents.

Several scholars, such as Beth Cohen, Adara Goldberg, and Françoise Ouzan, have explored the resettlement of Holocaust child-survivors in North America. ${ }^{3}$ In this burgeoning literature, photographs have often been overlooked, or only used as starting points or mere illustrations. Indeed, Beth Cohen suggests we need to learn from this material about individual children's lives. ${ }^{4}$ Bringing together recent works on humanitarian photography and on childhood in the immediate aftermath of the Holocaust, this article examines the visual discourses of the CJC's fundraising and home-finding campaigns and their later influence. It focuses predominately on a corpus of posters, illustrated pamphlets, and press articles broadly dating from 1947 and 1948.

There are two recurring patterns within the corpus: first, pictures of children in transit in Europe or during the transatlantic travel that would likely have been taken by relief workers and CJC staff that accompanied the orphans or were borrowed to other Jewish organizations involved in the process; and second, pictures of children upon arrival in Canada that may have been taken by social workers and community volunteers. ${ }^{5}$ The photographers of these images and the contexts of their production are unknown. The photographers were not credited and the captions only gave vague descriptions and dates. If this absence limits an in-depth examination of the photographers' profiles, it does not compromise the analysis of the pictures themselves: there is little doubt as to the 'ideological complicity' of the authors. ${ }^{6}$ They wanted to document and celebrate the work of the CJC. The imagery of the campaign is rich material: photographs and pamphlet illustrations embody an iconography of resettlement that had, I argue, a lasting influence on Canadian cultural memory and the cultural heritage of post-Holocaust migration. ${ }^{7}$

This article will examine three periods: the campaign itself (1947-1948), the early memorialization of the orphans' arrival in Canada (early 1960s), and the late memorialization (since the 1980s). By analysing the long history of this powerful visual material, I will demonstrate how its circulation shaped the ways in which the Holocaust was later represented and remembered and, fundamentally, contributed to the development of Canada's grand narrative as a country that welcomed refugees. ${ }^{8}$ 
In the late 1940s, the use of children in humanitarian appeals was not new. Heide Fehrenbach and Davide Rodogno have demonstrated that the 'figure of the dead or suffering child has been a centre-piece of humanitarian campaigns for over a century' and was present in earlier periods. ${ }^{9}$ The CJC's visual discourses in the campaign, however, highlight new trends in the representation of childhood and 'needy children'. ${ }^{10}$ Within the campaign, the CJC showcased a certain idea of the young newcomers by singularly addressing questions of age, gender, and normalcy, and navigating between different and often competing tropes: frail children and hard-working young adults, victims of war and desirable migrants. This article highlights the visual and material strategies behind these tropes, especially how the CJC attempted to position the project in a nationalist rhetoric, as well as the organization's struggles to grasp who the young survivors were, either children or adults.

These strategies bear some resemblance with other similar initiatives from Jewish organisations, especially in the United States, in Australia, and in South-Africa. The Canadian scheme, however, included older individuals that were not always eligible elsewhere. For instance, various South-African and Australian Jewish organisations set up resettlement projects that only accepted children under the age of twelve and sixteen respectively. The American and Swiss governments similarly set the age limit at sixteen, the former through the 1945 Truman directive and the latter for temporarily stay permits. ${ }^{11}$ The CJC was one of the few projects that immediately accepted applicants aged between 16 and 18. This choice radically impacted the demographics of the newcomers and, consequently, the way the organisation communicated about their arrival.

By documenting the project in a positive light, the pictures of the smiling young newcomers were also part of a longer-term agenda: reinforcing the historical significance of the orphans' arrival and, by doing so, building a public memory of the Canadian Jewish humanitarian response in the aftermath of the Holocaust. ${ }^{12}$ The imagery used in the fundraising and home-finding campaign is the largest and most-circulated visual material on the project. Through an examination of the memorialization of the orphans' arrival and its place in Canadian - Jewish and non-Jewish - cultural memory and heritage, this article demonstrates how the imagery impacted later representations of the Holocaust in Canada and provided a positive narrative of Canadian humanitarian responses that overshadowed the complicated history of the country toward refugees and child welfare, especially in the aftermath of the residential schools and Sixties Scoop scandals. ${ }^{13}$ This article highlights how the orphans, even when they became adults, were long absent from this memorialization. In the early campaign and for many years after, they were the voiceless faces of their resettlement: visible as objects of international charity, but silenced. This paradox, that photographs reinforced, only ended in the 1980s and 1990s: the shift both in Holocaust memory practices and childhood studies allowed them to be finally listened to and to offer a more complex narrative than the one the images of the campaign displayed.

\section{Campaigning through guilt and urgency}

The CJC scheme to bring Jewish orphans from Europe was authorized at the end of April 1947 after long negotiations with the Canadian federal government, provinces, and child welfare representatives. The organisation, founded in 1919, was predominantly active after 1934 and 
growing concerns about the rise of antisemitism in Quebec and worldwide. It had set up mobilisation campaigns in the late 1930s, such as German product boycotts, but remained in the margins of Canadian Jewish life. During the war, the Canadian Jewry did not manage to set up any large-scale evacuation of Jewish children. In October 1942, the CJC failed to bring 500 orphans from Southern France - a failure that highlights the difficulties of the organisation on the refugee issue and, more importantly, the hostility of the Canadian government. ${ }^{14}$ In the aftermath of the war, even though its position was still contested, a change in leadership with the arrival of Samuel Bronfman as president in 1939, and of Saul Hayes as executive director in 1942 has reinforced the CJC. ${ }^{15}$ Their ambition to set up the orphans scheme was part of a wider agenda to legitimise its place within the community.

The 1947 project was not a completely unprecedented initiative. In 1920, several isolated community members set up the Jewish War Orphans Committee of Canada. They managed to bring approximately 150 Ukrainian orphans, whose parents had died during pogroms. ${ }^{16}$ The 1947 project, however, was on a much greater scale. It had been initiated by the main organization of the Canadian Jewry in a dramatically different context. The federal government was pressured by child welfare representatives that had an ambitious professionalization agenda and by a Canadian public that strongly favoured a carefully selected immigration. Therefore, it had only accepted the project on very strict guidelines: first, the CJC would have the full legal and financial responsibility of the future newcomers. Second, it would have to prioritize foster care over any kind of collective solution, the institution being at odds with the new standards of Canadian child welfare.

In the summer, the CJC sent a team in Europe to plan the search and selection of candidates. It quickly became apparent that the majority of the future migrants would be teenagers. The first groups of orphans that arrived during the fall was indeed mainly composed of teenage boys. This pattern reflected both the demographics of Holocaust survivors and the politics of their resettlement: Jewish organizations were predominantly looking for young children that were considered more assimilable but only few survived the war. It had a significant impact on the project. Because the CJC had accepted full responsibility of the orphans and to only use foster care, the success of the project depended entirely on the organization's ability to quickly find funds and a sufficient number of families willing to welcome individuals that were way older than expected.

Figure 1: 'Failure Faces Orphans Movement' (Congress Bulletin, September 1947)

At the end of the summer of 1947, the CJC launched an intensive campaign to raise money for the transportation, resettlement, and care of the orphans and to find potential foster families within the community. Many representatives, rabbis, and public figures travelled across the country to talk in community meetings, but it was through the press that most of the communication was done. ${ }^{17}$ The CJC planned an extensive use of Jewish English-speaking and Yiddish-speaking newspapers because they were exclusively looking for Jewish foster families. CJC representatives frequently signed articles in newspapers such as the Canadian Jewish Review but the campaign's main support was the Congress Bulletin, the organization's monthly publication that was created to advertise its work and create a strong link with current and potential donors. The Bulletin extensively published on the project from fall 1947 to summer 
1948: the orphans found themselves at the very centre of the community's attention. In its representations of children, this campaign marked a break from the rhetoric of 'rescue' of the war and early post-war years.

In its September 1947 issue, the front-page headline focused on the urgency of the situation: 'failure faces orphans' movement unless homes are found for them' ${ }^{18}$ (Figure 1). In the accompanying article, one CJC representative was quoted saying that 'the children [were] healthy, cheerful, well-bred youngsters' and that social workers 'who are assisting in the project speak highly of the contribution that these youngsters can make to home life'. Another article, titled 'Will you open your home?', called upon every single Canadian Jew to take responsibility: 'If you say yes, the Congress will be able to bring one more Jew from Europe. If your answer is no, a Jewish orphan who might have come to Canada will be forced to remain in Europe'. ${ }^{19}$ The content of this first major publication set the tone for the whole campaign: make its readers feel guilty by emphasizing the urgency of the situation and the massive impact of every individual action; reassuring potential foster families by focusing on how 'normal' and promising the orphans were.

In the following months, many headlines - 'Shortage of homes Threatens Project', 'Jewish Foster Homes Urgently Needed for All' and so on - illustrate how the CJC strongly played on sentiments of urgency, fear, and crisis to quickly find homes for the young newcomers. Other campaign material, such as a pamphlet circulated during the fall of 1947, had similar content and visual strategies. The document's title 'If there's room in your heart, there's room in your home' formulated a simple equation: inaction meant indifference. In its introduction, the CJC director called for his readers' empathy and moral responsibility:

There is a Jewish child, in a European DP camp, who is waiting for you to let him begin to live. He is leaving behind a nightmare of death and ashes [...] yet he is optimistic, cheerful, full of the hope of youth [...] Today, no longer anonymous, no longer separated from your succor by an ocean, he stands at your very doorstep, needing a home, a family, the love and guidance of a father and mother. ${ }^{20}$

The pamphlet, like other campaigning materials, displayed a classic strategy: it emphasized the impact of individual actions by singularizing the potential donors and foster families. After the powerlessness of the war, every Canadian Jew now had the opportunity to make a difference by helping a young survivor to 'begin to live'. The simple narrative, the straightforward appeal to the emotions of the viewers, the individualization of the potential donor, and the focus on suffering '[framed] as unjust yet amenable to remedy' were all recurring patterns in post-World War 1 humanitarian rhetoric. ${ }^{21}$ The discursive techniques of the campaign were similar to the communication practices developed by charities like Save the Children in the 1920s as well as by most north American Jewish relief organisations during the Second World War (with headlines and captions like 'Will you help?'; 'Your gift may stand between a child and death', 'Now or never', etc.). ${ }^{22}$ However, this campaign embodies newer trends in the humanitarian representations of children: no longer depicted as passive victims, children were now portrayed as resilient soon-to-be Canadian citizens.

\section{Portraying resilient and normal future citizens}


One obvious pattern in the CJC campaign's imagery contrasts with the focus on emotions of guilt and urgency: the representations of children were extremely positive. All the photos used showed smiling and attractive children, often involved in very childlike activities (eating icecream, attending a sport event, etc.). Like the three orphans pictured disembarking an aeroplane (Figure 1), the arrivals of young survivors were always framed as scenes of collective joy and enthusiasm. The many optimistic and aesthetically familiar pictures sent a clear message to the readers: these children were already normal children, despite their difficult experiences. This illustrated and reinforced the accompanying narratives that told stories of resilience and 'normalcy'. In the Canadian Jewish Review, a CJC representative insisted that, 'despite the fact that most of the children have gone through untold hardship they have retained a wonderful balance'. ${ }^{23}$ The pamphlet 'If there's room in your heart...' presents five orphans' short biographies (Figure 3): 'Michael's past is ashes but his future is bright', Mimi 'refused to bow before the tragedy that befell her family in Romania [...] her smile will assure you that such children as Mimi know how to rise from ruin and build anew', Benjamin 'is a tower of strength [...] he never wavered, never compromised his deep and simple faith' ${ }^{24}$ Narratives went often beyond resilience: these children had not only survived the war, they had developed skills and had come out stronger. Philip, for instance, 'when things looked blackest during nine months at Buchenwald, never lost hope, planned for the future, and kept the electric lights working in his huts'. ${ }^{25}$ The boy was not a passive victim as he even found a way to improve his training while in a concentration camp. Such depictions were recurring in the campaign and reinforced its 'redemptive message ${ }^{26}$ : the war was not invisible but was already a distant past. Images played an essential role in its domestication.

Acknowledging while also distancing the war, the CJC simultaneously attested to the orphans' status as victims who deserved to be saved and their attractivity as newcomers that would contribute to the country and its Jewish community. The campaign's rhetoric thus constantly navigated between two tropes: genuine victims of war and ideal migrants. The orphans' resilience and the many skills they had gained during the war made them adaptable and desirable future citizens that would, like Philip, 'take to Canada like a duck to water' (Figure 3). ${ }^{27}$ This assimilationist rhetoric was reinforced by the campaign's imagery. For instance, in the October 1947 issue of the Congress Bulletin, a group of orphans is portrayed around a table interacting with adult staff members, somewhere on their way to Canada. The legend states "What's Canada like?" [...] Here the orphans eagerly learn about their nativeland-to-be'. Despite predominantly coming from small rural communities in Poland, Hungary, and Romania, the orphans were always pictured in North-American outfits and had an already western look. Their names, when displayed, were anglicised overshadowing their non-British origins (Figure 3). Moreover, the more religious individuals whose outfits might have clashed with an idealized notion of childhood were visually absent from the campaign. Even though the call was targeted at a Jewish audience, its imagery portrayed a Jewishness that was in line with Canadian customs and with the largely assimilationist agenda of the community elite. The Jewish identities of the children were not erased but strongly Canadianized.

The focus on the orphans as future citizens that would quickly contribute to their new country echoed discourses on childhood and on 'worthy refugees' that developed in the interwar period and became prominent in the post-war era. ${ }^{28}$ It played a significant part in the CJC's strategy of legitimization on many levels. It strengthened the idea of a reciprocal usefulness of 
the project between the Jewish community and the State, as the admission of the orphans fit both the country's humanitarian engagement and economic self-interest. ${ }^{29}$ It justified the efforts of the CJC that dedicated most of its staff and spending to the project. It encouraged the human and economic investment of donors and foster families as well: getting involved in the project was not only a way to help fellow European Jews, it meant contributing to the transition of Canadian economy from war to peace. Finally, this insistence may also have been a response to the many fears about the lost identity of European children and the need of 'renationalizing' them: the orphans had already a strong sense of belonging to their new country. ${ }^{30}$

This positive depiction of children as joyful future citizens embodies newer trends of an iconography of resettlement that became widespread during the Cold War. As Mary Tomsic has demonstrated with the case of Australia, migrants were increasingly depicted as ideal new citizens, 'freedom loving with democratic values and a violent past that was firmly behind them' ${ }^{31}$ It also represents a significant shift in the campaigning strategies of the CJC. The dark visuals of desolated landscapes, concentration camps and barbed wires, scared faces and human remains and of narratives - 'A matter of life!', 'Do not forget your brothers!', 'The end of Hitler brings you the opportunity to rescue the living! ${ }^{32}$ - of the war years were quickly replaced by more optimistic accounts and pictures. Only one pamphlet circulated in May 1948 displays a very different visual strategy than the other materials used in the campaign. And yet, the document does not focus on the atrocities of the war or on the poor living conditions in postwar Europe but addressed the emotionally-charged issue of hidden Jewish children placed in Christian foster families or institutions during the war (Figure 2). Its aggressive title and font ('From shmad [destruction in Yiddish]... From shame... From shambles... Deliver them!') are accompanied by the picture of a frightened girl and an article that seems to be taken from the Jewish Telegraph Agency - the use of photographs with actual press clips being a recurring technic in humanitarian and safety appeals in the 1940s and 1950s. ${ }^{33}$ The girl looks in the direction of the press clipping that stated that 'because British Jews did not respond fully to appeals for accepting Jewish refugee children into their home at least 129 Jewish orphans of some 9,300 who found haven in England since 1933 have been baptized'. ${ }^{34}$ An enthusiastic response from Canadian Jews would contrast with the failures of British Jewry. This guilt and fear-based rhetoric was a common pattern for Jewish organizations in the aftermath of the Holocaust: after the Nazis, the children, as the future of world Jewry, had to be saved from Christian proselytism. ${ }^{35}$

Figure 2: pamphlet 'From Shmad...' (CJC series FA3 box 1 file 5, May 1948)

The absence of such negative and darker imagery from the campaign reflects a shift in visual strategies that can be explained in several ways. It could be first explained by the evolution of the CJC's agenda, from short-terms rescue and relief to longer-terms resettlement efforts. As demonstrated, positive depictions of the children were a way to insist on their normalcy and reassure the potential foster parents. It also represents a broader evolution in humanitarian visual politics. The campaign was not only a break with the war years' imagery but also with the 1920s-1930s humanitarian appeals of organizations such as the World Jewish Relief that frequently used shocking pictures of 'starving abandoned orphans' ${ }^{36}$ This evolution is even more visible when one compares the imagery of the late 1940s project with the rather 
similar initiative of the early 1920s when community members managed to bring approximately 150 Jewish Ukrainian orphans to Canada. The accompanying narrative that was used in newspapers and on greeting postcards during the 1920s is relatively close from the 1947 campaign: the children were described as 'unusually intelligent' and already presented as 'future Canadian - Jewish citizens ${ }^{\text {' }}$. The imagery, however, strongly differs. The worn-out gowns and sad facial expressions of the Ukrainian children contrast with the well-clothes and smiling newcomers in 1947. The majority of them are posed group pictures in the tradition of school or classroom photography. ${ }^{38}$ The children's uniformed short haircuts and dirty grey clothes tend to erase even more the differences between the individuals. The few full-body or portrait pictures still have neutral framing and backgrounds - often in outdoor setting echoing ethnographic tradition or in front of a grey drape as it was usually the case for identification photography. ${ }^{39}$ Even the few children that were pictured in childlike activities - especially playing with toys - sadly or confusingly starred at the photographer. Despite sharing similar goals and medium, the two campaigns used very different visual vocabularies in their campaign: one of fear and pity in the 1920s; one of joy, hope, and normalcy in the 1940s.

This gap illustrates the evolution of photographic techniques and the dramatically different context of both projects, but also confirms wider changes in humanitarian communication practices, that sought to override the negative emotion of crisis with the constructive forces of resettlement and nation building. The 1947 project predominately used positive images of the children and went beyond than describing them as 'future Canadian Jewish citizens'. It portrayed them as joyful, optimistic, and normal Canadian citizens in the making. Its visual discourses also strongly differed from the tropes of 'disfigured bodies and psyches', 'accidental veterans', and 'displaced children' that were at the centre of many works, Thérèse Bonney's (1943) or David Seymour's (1948) being among the most celebrated. ${ }^{40}$ By focusing on normalcy and familiarity, the campaign distanced itself from appeals that used shocking images to '[make] news stories and aid appeals seem both urgent and ethically transparent. ${ }^{41}$ It also differed from other appeals that showed both 'needing children' and 'success stories. ${ }^{42}$ Contrasting with its accompanying narratives of emergency and calls for individual responsibility, the visual discourses of the campaign were only focusing on positive representations: the project was already a success.

\section{Portraying children, adolescents, or young adults}

Several scholars, including Tara Zahra and Beth Cohen, have rightly pointed out the 'startling gap' between the representation of very young children in humanitarian appeals and the demographic realities of the Holocaust survivors as a population. ${ }^{43}$ Images of 'rosy and happy babies', aimed at convincing potential donors and foster families, were widespread especially in 'early media coverage of the war orphans' ${ }^{44}$ Conversely, the CJC campaign displays a more complex reality in the way it addressed who the young newcomers were exactly. The question of age was especially crucial for the CJC. The demographics of the orphans - predominantly teenage boys - contrasted with the expectations of foster families. As one of the project representatives pointed out, the majority of the applications were for 'children below the age of 16 without family ties in the US or Europe', especially girls. ${ }^{45}$ The numerous withdrawals of applications when such requests could not be met placed the CJC in a delicate position and 
forced them to enhance their efforts to convince potential families and donators. It resulted in an ambivalent portrait of adolescence with a gap between the visuals and the narrative of the campaign. On one hand, the imagery tended to focus on younger and female orphans. On the other hand, the accompanying narrative often straight-forwardly addressed the actual age of the newcomers. In an article of the Canadian Jewish Review, a CJC representative stated that 'the majority of the 'children' could more be aptly described as adolescents' ${ }^{46}$ In the September 1947 Congress Bulletin issue, one of the main articles explained that 'most of them are on the threshold of their own lives. They are ready to go to work and to share with their new-found friends here the pleasure of discovering the joys of normal living in the new world' ${ }^{47}$ The CJC interestingly tried to make the problem part of the solution: the orphans were 'nearly ready to start upon their own lives in our country', it would '[meant] that our responsibilities will be of shorter duration and that we will be adding more quickly to the ranks of the adult Jewish community'. ${ }^{48}$

Figure 3: excerpts from the pamphlet 'If there's room in your heart, there's room in your home' (CJA, UJRA Collection, War Orphans Project, series Ca, box 25, Administration, General)

Even though the organization frequently admitted the orphans were older, it still obviously struggled to address who they were exactly. The short biography of Benjamin in the pamphlet 'If there's a room in your heart...' perfectly illustrates this tension (Figure 3): his age appears clearly in the section's title - 'Benjamin is eighteen' - and the boy is presented as strong 'in character and physique'. ${ }^{49}$ In the description of his wartime heroism, a formulation - 'when yet a child' - confirms that the boy was no longer regarded as a child. His biography, however, ends by stating that he '[needed] a home, a father'. Despite his age and early maturity, Benjamin had still to be sent in a family to be under the supervision of new parents. This example reveals the ambivalent rhetoric of the CJC that both depicted the orphans as vulnerable children (infantilization) and self-sufficient soon-to-be adults (adultification). This tension could be explained by the relative newness of adolescence as a concept, despite the 'intensification of interest' in the 1930s and 1940s that would predominantly take off in the $1950 \mathrm{~s}^{50}$. It could also reflect the difficulties the CJC faced matching its humanitarian ambitions and familialist ideal - giving each orphan the chance to have a new family and an education - with a more pragmatic financial reality that led the organization to push the young survivors toward self-sufficiency. All along the project, the CJC hesitantly navigated between two competing agendas: reinforcing the orphans' childness or rushing them to adulthood.

This confusion was reinforced by the gap between the narrative of the campaign and its imagery. Beside the sketches in the pamphlet 'If there's room in your heart' that clearly represented the orphans as confident teenagers (Figure 3), the photographs predominantly showed younger, more 'childlike' individuals. One of the first images used, on the frontpage of the September 1947 Congress Bulletin, tends to confirm a focus on young girls (Figure 1). It shows Lucienne Z., aged 11, by far the youngest child and one of the only three girls of the twenty orphans that arrived with her. She is depicted with another girl whose name is unknown disembarking from the plane that brought them from Halifax to Montreal (her older brother Jacques can also be seen in the background). Both girls appear one more time, Lucienne on page 4 alongside her brother and the other girl on page 2 'enjoying her first ice-cream cone at 
the Dorval airport soon after landing in Canada'. This pattern is confirmed in the later issues of the Bulletin that gave a visibility to younger and female orphans that far exceeded their actual number within the group. While regularly acknowledging that the majority of the orphans were teenage boys, the CJC predominantly portrayed young children 'unambiguously vulnerable and dependent' to convince hesitating donors and foster families. ${ }^{51}$

The campaign imagery also reveals another recurring issue in the representation of children in humanitarian appeals: the issue of personalization. Personalizing - focussing on distinct individuals - both the recipient and singularizing the donor 'as an individual who can make a difference in a practical way' have long been utilised in humanitarian communication as strategies to capture the public's attention. ${ }^{52}$ The focus on individual actions' impact has already been highlighted in this article, the campaign's narrative being framed around the idea of putting every single Canadian Jewish person in front of their moral responsibilities. Yet, the personalization of the orphans to engage the readers' emotions is less evident in the campaign materials. In the post-war period, the ethical implications of representing children in humanitarian appeals and the necessity to guaranty the protection of the recipients' privacy were frequently discussed, especially within Jewish organization involved in the rescue and rehabilitation of children in Europe.

As demonstrated by Maggie Fraser Kirsh, the Zionist leader Henrietta Szold, founder of the Youth Aliyah and of Hadassah Women's Zionist Organization of America, quickly addressed these questions in the immediate aftermath of the Holocaust. ${ }^{53}$ Szold constantly refused to provide detailed stories about the children she had taken care of and always favoured publicity that did not reveal their identities. Other organizations bypassed these privacy issues to secure funding. ${ }^{54}$ There is no record of similar discussion on the matter within the CJC representatives' correspondence and memorandums, but their choice of imagery and the accompanying narratives' content confirm that the Canadian organization emphasized on pictures of groups rather than individuals. The majority of the pictures show collective scenes with captions using words such as 'group', 'party', or 'contingent'. There were some personalization efforts but that remained vague. For instance, the five orphans presented in the pamphlet 'If there's a room in your heart...' (Figure 3) are one of the only occurrences of displaying first names and biographies. Even then, the stories were not very detailed and further research in the archives seems to indicate that they were fictional. Press articles as well gave very little information about the children. For instance, the only detail about the two siblings from the September 1947 issue of the Bulletin are that they were 'of Turkish-Jewish origin'. The CJC prioritized portraying childhood (as an abstract idea) instead of children (as distinct individuals). By doing so, it elided the boundaries between very young children, teenagers, and young adults and widened the image of childhood itself.

\section{Celebrating Canada's tradition of welcome}

In 1948, just a year after the beginning of the CJC orphans' project, a pamphlet presented the scheme as 'the greatest undertaking in the annals of Canadian Jewry' ${ }^{55}$ It insisted on the community's positive collective response with foster homes existing 'from Halifax to Vancouver' and on the orphans' quick contribution to 'the richness of Canadian living and to the strength of the Canadian Jewish community'. The document concluded: 'No other Jewish 
community outside of Palestine has accomplished as much in this direction. The war orphans project is a continuing source of pride to Canadian Jewry and one of its greatest achievements.' Indeed, by 1948 the CJC was already involved in shaping the public memory of the orphans' arrival. This 'self-conscious performance of historical significance ${ }^{56}$ had, this article argues, a lasting impact on the memorialization of the Holocaust in Canada. With the exception of some photographs taken by social workers and foster parents that had a limited circulation, the pictures used during the fundraising and house-finding campaign were the only imagery of the project and consequently played a crucial role in this process: they influenced how the Holocaust was later remembered and represented in Canadian cultural memory and heritage.

Before further addressing this influence, it is essential to give an overview of the memory and memorialization of the project as the orphans' individual and collective stories figure singularly in the Canadian Jewish and non-Jewish national narratives. The memorialization of the Holocaust in North America has been at the centre of heated public and scholarly debates. Peter Novick in the United States and Franklin Bialystok in Canada have argued, among others, that the Holocaust has an 'unusual chronology' as it was absent from North-American public memory and cultural heritage before the 1970s. ${ }^{57}$ It was the Eichmann trial (1961-1962) and moreover the Six Days War (1967), the Yom Kippur War (1973), and the broadcast of the miniseries Holocaust (1978) that contributed to the Holocaust's current importance. In recent years, this timeline has been widely criticised, especially by Hasia Diner that has offered a counternarrative and rejected the 'myth of silence' in the aftermath of the Holocaust. ${ }^{58}$ Novick and Bialystock were accused of focusing too much on Jewish elites and ignoring what Eli Lederhendler has called the 'subterranean Holocaust awareness' that quickly developed in private Jewish spaces. ${ }^{59}$ The memorialization of the orphans' project complexifies the chronology defined by Novick and others as their arrival was celebrated as early as 1962 and had since occupied a fluctuating place in Canadian cultural memory and heritage.

Figure 4: Maclean's (10 February 1962)

The first significant step in the memorialization of CJC campaign happened around the tenth anniversary of its official closure. In June 1959, the UN launched their World Refugee Year to 'give Governments the opportunity of increasing the proportion of refugees to be included in immigration programmes and of liberalizing selection criteria'. ${ }^{60}$ The orphans' resettlement was repeatedly mentioned during related events in Canada. It was, for instance, described as 'one of the earliest post-war humanitarian movements to Canada' by Ellen L. Fairclough, then Minister of Citizenship and Immigration, in a speech to a women council in Hamilton. ${ }^{61}$ In 1962, the project was the topic of a book published at the University of Toronto Press and made the cover of Maclean's, one of the largest mainstream English-Canadian newspapers. The issue celebrated 'one of the great humanitarian act of the twentieth century' and the response of Canada that welcomed 'one of every four children who survived the Nazi death camps' (Figure 4). It used one of the many pictures of orphans in transit and shows the youngest girl in the whole group, aged 7, when she arrived in Canada. This choice perpetuated the trend of the 1947-1948 appeal that predominantly focused on young 'childlike' female orphans. The visuals and narrative of the Maclean's article confirms another trend of the campaign: it strongly insisted on the project's inclusion in the national narrative. While 
acknowledging that the scheme was carried by a Jewish organisation for Jewish children, the article's author insisted on its importance for the Canadian society: the young survivors were fostered by 'Canadian families' and had now 'set their roots deep in Canada'. ${ }^{62}$ This reflects how the Jewish specificity was absent from early Holocaust memory practices, what Belgian historian Pieter Lagrou calls 'déjudaïsation'. ${ }^{63}$ The orphans were referred by the Maclean's associate editor as a 'rich human harvest', a rhetoric that echoed longstanding discourses on children, especially orphans and abandoned children, as a 'natural resource' and a 'human treasure' that should be protected by nation states. ${ }^{64}$ The young survivors were truly part of the Canadian post-war 'success story'.

If its importance within Jewish spaces, especially private, should be acknowledged, the Holocaust was on the margins of Canadian public memory in the early 1960s. So, how can one understand this celebration of the orphans' arrival? As American historian of science Owen Gingerich pointed out, every commemoration and collective effort of remembrance has a 'background agenda' ${ }^{65}$ In this case, the celebration of the orphans' arrival seems to reflect two main needs: first, reinforcing the idea of a Canadian tradition of welcome and second, legitimizing the work of Jewish welfare organizations. In 1959, the World Refugee Year put refugees at the forefront of public debates in Canada. The conservative government, elected in 1957, was reluctant to make any consequent change of its immigration and refugee policies. ${ }^{66}$ The orphans' project thus contributed to reinforcing its position: Canada had already taken its fair share of refugees and could be proud of its tradition of welcome. ${ }^{67} \mathrm{CJC}$ representatives had a similar discourse but with a slightly different agenda. The organization was involved in the Canadian Committee for World Refugee Year (CCWRY). It insisted on its 'considerable experience [...] in assisting in the rescue, relief and rehabilitation of victims of concentration camps after the liberation of Europe' and claimed its legitimacy to get involved in 'the worldwide plans to bring succor and relief to those who deserve and will appreciate it'. ${ }^{68}$ As for the Canadian government, the orphans attested the CJC's early humanitarian action, especially because the World Refugee Year came close to the tenth anniversary of the project. The narrative developed during the appeal - one of success and historical significance - was used once again for several purposes. As the organization's vice-president wrote in the preface of the book on the project, 'the story bears testimony to the readiness on the part of the Jewish community of Canada and of the Canadian Government to welcome these children in this country in the days when the immigration doors were all but tightly shut'. ${ }^{69}$ The orphans' project not only showcased the Canadian Jewish contribution to the country and its tradition of welcome but also justified the CJC's legitimacy as the leading organization of the community.

The earliness of this memorialization makes it significant and unique. It reflected not only the increased visibility of the Holocaust in North-America but also the growing importance of the figure of the child-refugee in Western cultural memory. The orphans themselves, however, were absent from this early celebration as their voices were triply silenced: they were Holocaust survivors that had little opportunities to be listened by the established community; they were recent immigrants that did not have much influence on the national narrative; and they were still 'children' - even though they had now become adults - whose credibility was denied in an adults' world. The pictures reinforced this paradox. It was illustrated by one caption of the Maclean's article that referred to the three orphans on a photograph as 'these survivors of genocide... among many who can no longer be traced by the Jewish Congress' ${ }^{70}$ The young 
survivors had become what Liisa Malkki described as 'speechless emissaries' as their visibility strongly contrasted with their silence. ${ }^{71}$

\section{Overshadowing Canada's uneasy past?}

The celebration in the late 1950s and early 1960s of the arrival of the orphans to Canada was short-lived. ${ }^{72}$ In the book celebrating the fiftieth anniversary of the CJC in 1969, there was just one sentence about it and a picture of orphans 'en route to Canada' ${ }^{73}$ It was only in the 1980s and 1990s that the orphans' project was unravelled once again and this time, established deeper roots in Canadian cultural memory and contributed to a broader understanding of the heritage of the Holocaust ${ }^{74}$. This second wave differed from early memory practices on one very significant aspect: the orphans were now central to the memorialization of their arrival. They benefitted from what French historian Annette Wieviorka called the 'era of the witness' (ère du témoin ${ }^{75}$ ) as many were involved in oral testimonies projects such as the CJC's Holocaust Documentation Project, the Shoah Foundation for Visual History and Education or, later, Concordia University's Montreal Lifestories. ${ }^{76}$ Their testimonies revealed a more complex reality that, not surprisingly, contrasted with the sentimentalized depictions and celebratory narratives of the 1947-1948 campaign. Many orphans insisted on the many disillusions upon their arrival and the frequent tensions with foster families and social workers. Others remembered how few people were willing to listen to their stories. ${ }^{77}$ Even within survivors' spaces, children's accounts were often delegitimized. ${ }^{78}$ Going through the CJC archives confirmed these difficulties, especially with the foster families. For instance, out of the 137 orphans sent to Winnipeg, 92 had moved from foster families at least once and 28 of them changed more than four times. ${ }^{79}$ Similar difficulties also existed in Montreal, Toronto, and Vancouver. This reality was virtually absent from the visuals of the project. For instance, Jacques Z., the young boy that was pictured smiling freshly out of the plane with his younger sister Lucienne (Figure 1), had a complicated relation with his new country. In contradiction with the CJC's advice, he decided to come back to France in the beginning of the 1950s, being frustrated by his situation, before finally migrated once again to Canada not long after. ${ }^{80} \mathrm{Such}$ complexity is not completely erased but often overlooked in the long-term memorialization of the orphans' arrival.

In 1996, the Martz's book was published and was followed the next year by an exhibition that was developed and presented at the Vancouver Holocaust Education Centre (VHEC) ${ }^{81}$. It was later transferred online (and is still available on the Virtual Museum of Canada's website ${ }^{82}$ ) and was once again presented at the VHEC in 2016 'to provide opportunities for visitors to engage with Canadian refugee policies from a historical perspective' ${ }^{83}$ The project also has an important part in the permanent exhibition of the Montreal Holocaust Memorial Centre and in their recent virtual exhibition 'Building New Lives', as well as in the Canadian Museum of Immigration (Pier 21) in Halifax whose website hosts several orphans' testimonies. It was also frequently covered by the Canadian Jewish and non-Jewish press in the $2000 \mathrm{~s}$ and the $2010 \mathrm{~s} .{ }^{84}$ This coverage confirms the influence of the 1947-1948 campaign. The titles of the exhibition and of the book - respectively 'Open Hearts - Closed Doors' and 'Open your heart' - and their imagery - the majority of the book's illustrations and two of the nine 'artefacts' presented in the exhibition's section on the orphans' arrival in Canada were from the campaign - directly 
draw on the campaign's vocabulary. Almost all the press articles also used pamphlets and photographs from the 1947-1948 appeal.

This growing visibility could be explained because the orphans' arrival positively linked the Canadian national narrative to the history of the Holocaust. The country's government and Jewish community were quickly involved in the rescue and rehabilitation of the most vulnerable population among Holocaust survivors. Its optimistic narratives and representations match the growing needs for 'making the history of the Holocaust accessible to increasingly younger audiences' and for '[connecting] students to children during the Holocaust without featuring atrocity' ${ }^{85}$ It also contributes to an optimistic depiction of children in Canadian history, which had been darkened by several massive scandals about the British Empire's 'lost children' and the aboriginal residential schools. ${ }^{86}$ Recently, it strongly resonated with the arrival and care of unaccompanied minors fleeing the Syrian civil war and reinforced once again the country's narrative of early humanitarianism and tradition of welcome especially of children, overshadowing its 'complicated history' with refugees. ${ }^{87}$

The latest occurrence of its memorialization confirms the importance of the orphans' arrival in Canadian cultural memory and heritage. In the spring of 2016, a 4-year multimedia exhibition was launched as part of a series of events celebrating the $375^{\text {th }}$ anniversary of the foundation of Montreal. The exhibition, called Cité Mémoire, was created by two renowned Québécois directors and was composed of 19 tableaux. These three to six minutes videos were projected in various areas of the city and introduced passers-by to key-moments of its history. ${ }^{88}$ One of these tableaux, 'The Jewish Children's Transport Train 1947', focused on the arrival of one Jewish orphan in Montreal and his first encounter with his new foster family (Figure 5). ${ }^{89}$ The foster father is played by the son of Jacques Z., the young boy that was pictured with his sister (Figure 1). ${ }^{90}$ The fact that the War Orphans Project was chosen alongside the 1849's burning of the Parliament or the 1967's Universal Exhibition as one of the key-moments of the city's history highlights its singular position within Canadian cultural memory and national heritage.

The creative process of the two directors is unknown but their choice seems to fit the need of paying tribute to the city's Jewish history through an event that was easily communicable to the public. Moreover, the story of the orphans welcomed by 'Montreal families' reinforced once again the image of a city and a country opened to disserving refugees. The tableau also demonstrates the limits of the visual discourses of the 1947-1948 appeal. The two directors distanced themselves from the optimistic representations that prevailed before. The smiling faces of the campaign were replaced by another trope: the young boy's hollowed face, sad expression, grey clothes, and short hair strongly echoes the figure of the camp survivor. It still heavily relies on the familialist ideal developed by the CJC and on 'sentimentalized notions of parent-child bond" ${ }^{91}$ that were and still are recurring in humanitarian appeals: the story focuses on the orphan's first encounter with his 'new parents' that were going to play the central role in the young survivor's success in Canada.

Figure 5: photograph of the tableau The Jewish Children's Transport Train 1947 (Canadian Jewish News) and screenshot of the Cité Mémoire's app (Montréal en Histoire)

\section{Conclusion}


This article has argued that early representations of young Holocaust survivors had a lasting influence on Canadian - Jewish and non-Jewish - cultural memory and heritage. The 19471948 campaign and its visual discourses reflect various trends of the history of humanitarian photography, especially the increasing importance of the figure of the child victim. They were not entirely new as they drew on rhetoric of emergency and guilt that was common since the First World War. They also participated in newer trends that predominantly developed after World War 2 with organizations like the United Nations Relief and Rehabilitation Administration (UNRRA) or the American Jewish Joint Distribution Committee (AJDC) that based their communication on positive imagery of childhood. ${ }^{92}$ This iconography of resettlement reflected many concerns of the era. Travel and arrival pictures represented the orphans' transition from war (victims) to peace (citizens), from a weakened European Jewish identity to a well-established Canadian identity, and, although less apparently, from childhood to adulthood. They reinforced the growing 'language of children as the future' ${ }^{93}$ and, more broadly, the perception of children as 'becoming rather than being'. ${ }^{94}$ By telling stories of resilience and success, these images embody the hopes of a quick return to normalcy after the war. By portraying children that were already 'Canadianized', they positioned the project in the national narrative and showcased the contribution of the Jewish community to Canada's internationalism and domestic interests.

These visual discourses had a significant impact on the memorialization of the Holocaust in Canada. The positive and 'Canadianized' portraying of children was repeatedly 'repurposed ${ }^{95}$ to celebrate Canadian Jewish and non-Jewish humanitarianism. In the 1960s, they reinforced the country's perceived tradition of welcome. After the 1980s, they provided a positive image of Canada's response to the Holocaust and overshadowed the indifference and stubbornness of its government and the powerlessness of its Jewish community during the war years. ${ }^{96}$ Recently, they were once again utilized to strengthen the image of Canada's tradition of welcoming refugee children at a time where the liberal government was advertising its humanitarian involvement in the Syrian crisis. By analysing the Jewish contribution, this article calls for further research on the making of this tradition of welcome to understand how internationalism and humanitarianism had become 'an entrenched part of [Canada's] national mythology'.97

Now well-established in Canadian cultural memory and heritage, the project had a singular memorialization process. The orphans were long absent from it and it was only in the 1980 s that they gradually went from 'speechless emissaries' ${ }^{98}$ to being dominant voices. Their testimonies offered a more nuanced narrative than the one the images of the campaign showcased. This article had demonstrated, however, the persistence in recent representations of the orphans' arrival of the visual discourses developed during the fundraising and house-finding campaign. Even the images of 2016's Cité Mémoire that distanced themselves from an overoptimistic imagery still cling to idealized notions of parenthood and family that were at the very centre of the 1947-1948 appeal. The story of the orphans still remains overwhelmingly about resilience, integration, and success. The scene itself encompassed all the tropes of the campaign: genuine war victim, vulnerable child needing the love and guidance of his new parents, and ideal newcomer ready to contribute to his country. Such tropes say little about the young survivors themselves but say a lot more about Canada's national identity and complex relations with its past. 
${ }^{1}$ Tara Zahra, The Lost Children. Reconstructing Europe's Families after World War II (Cambridge: Harvard University Press, 2011).

${ }^{2}$ For an overview of the project, see Ben Lappin, The redeemed children (Toronto: University of Toronto Press, 1963); Fraidie Martz, Open your Hearts (Montreal: Vehicule Press, 1996).

${ }^{3}$ Beth Cohen, Child Survivors of the Holocaust. The Youngest Remnant and the American Experience (New Brunswick: Rutgers University Press, 2017); Adara Goldberg, Holocaust Survivors in Canada. Exclusion, Inclusion, Transformation, 1947-1955 (Winnipeg: University of Manitoba Press, 2015); Françoise Ouzan, How Young Holocaust Survivors Rebuilt Their Lives. France, the United States, and Israel (Bloomington: Indiana University Press, 2018).

${ }^{4}$ Beth Cohen acknowledges the role of photographs as a starting point for her research, stating that images of children in the postwar media pushed [her] to learn more' about their individual trajectories; Cohen, Child Survivors of the Holocaust..., pp. 1-2.

${ }^{5}$ Ethel Ostry, one of the main CJC representatives in Europe gathered her own pictures in a photo album.

${ }^{6}$ Simone Gigliotti, 'Displaced children of Europe, then and now: photographed, itinerant and obstructed witnesses', Patterns of Prejudice, 52, 2-3 (2018), p. 162.

${ }^{7}$ Drawing on Laura Briggs' 'visual iconography of rescue', Laure Humbert had examined UNRRA's 'iconography of repatriation', Laure Humbert, Reinventing French Aid: Displaced Persons in French-occupied Germany, 1945 1952 (work in progress); Laura Briggs, 'Mother, Child, Race, Nation: The Visual Iconography of Rescue and the Politics of Transnational and Transracial Adoption' in Gender \& History, 15, 2 (2003), pp. 179-200; see also Silvia Salvatici, 'Sights of Benevolence. UNRRA's Recipients Portrayed' in Heide Fehrenbach and Davide Rodogno (eds), Humanitarian Photography: a history (Cambridge: Cambridge University Press, 2015), pp. 200222. On the entangled relation between the two key-concepts, see Dacia Viejo-Rose, 'Cultural heritage and memory: untangling the ties that bind', Culture \& History. Digital Journal, 4, 2 (2015), online (http://dx.doi.org/10.3989/chdj.2015.018 viewed on 5 June 2018).

${ }^{8}$ On visual culture after the Holocaust, see Marianne Hirsch, The Generation of Postmemory. Writing and Visual Culture After the Holocaust (New York: Columbia University Press, 2012); James E. Young, At Memory's Edge After-Images of the Holocaust in Contemporary Art and Architecture (New Haven: Yale University Press, 2002).

${ }^{9}$ Heide Fehrenbach and Davide Rodogno, "A horrific photo of a drowned Syrian child": Humanitarian photography and NGO media strategies in historical perspective' in International Review of the Red Cross, 97 (2015), p. 1121.

${ }^{10}$ Heide Fehrenbach and Davide Rodogno, 'Introduction' in Fehrenbach and Rodogno (eds), Humanitarian Photography..., p. 8.

${ }^{11}$ Suzanne D. Rutland, 'A Distant Sanctuary: Australia and Child Holocaust Survivors' in Simone Gigliotti and Monica Tempian (eds), The Young Victims of the Nazi Regime. Migration, the Holocaust and Postwar Displacement (London: Bloomsbury, 2016), 71-90; Michele Langfield, 'Memories of Jewish Child Refugees in Australia', Holocaust Studies. A Journal of Culture and History, 16, 3 (2010), 79-94; Leonard Dinnerstein, 'Truman, Holocaust Survivors and Palestine' in R. Daniels (ed.), Immigration and the Legacy of Harry S. Truman (Kirksville: Truman State University Press, 2010), 24-49; Daniel Gerson, 'Refuge Without the Right to Permanent Residence: Holocaust Survivors In Switzerland, 1945-1955', Jewish History Quarterly, 2 (2013), 340-347.

${ }^{12}$ This assertion draws on Clark's idea of photography's role in a 'self-conscious performance of historical significance', Catherine E. Clark, 'Capturing the Moment, Picturing History: Photographs of the Liberation of Paris', The American Historical Review, 121, 3 (2016), p. 831. See also the efforts of UNRRA to 'create a public memory' of its work; Salvatici, 'Sights of Benevolence', p. 201.

${ }^{13}$ Holly A. McKenzie, Colleen Varcoe, Annette J. Browne, and Linda Day, 'Disrupting the Continuities Among Residential Schools, the Sixties Scoop, and Child Welfare: An Analysis of Colonial and Neocolonial Discourses', The International Indigenous Policy Journal, 7, 2 (2016).

${ }^{14}$ See Irving Abella and Harold Troper, None is too many: Canada and the Jews of Europe, 1933-1948 (Toronto: Lester, 1991 [1982]); David Fitzgerald and David Cook-Martin, Culling the Masses. The Democratic Origins of Racist Immigration Policy in the Americas (Cambridge, London: Harvard University Press, 2014), 141-185.

15 See Franklin Bialystok, Delayed Impact. The Holocaust and the Canadian Jewish Community (Montréal, Kingston: McGill-Queen's University Press, 2000).

${ }^{16}$ Gerald Tulchinsky, Canada's Jews: A people's journey (Toronto: University of Toronto Press, 2008), pp. 223227.

17 Canadian Jewish Archives (CJA), Inter-Office Information (I.O.I.), volume 3, 12 September 1947; I.O.I., volume 3, 22 September 1947.

${ }^{18}$ Congress Bulletin, September 1947, p. 1.

${ }^{19}$ Congress Bulletin, September 1947, p. 24.

${ }^{20}$ CJA, pamphlet 'If there's room in your heart, there's room in your home', UJRA Collection, War Orphans Project, series Ca, box 25, Administration, General, p. 2. 
${ }^{21}$ Fehrenbach and Rodogno, 'Introduction', p. 6; for a contemporary perspective, see Laura Suski, 'Children, Suffering, and the Humanitarian Appeal' in Richard Ashby Wilson and Richard D. Brown (eds.), Humanitarianism and Suffering. The Mobilization of Empathy (Cambridge: Cambridge University Press, 2009), pp. 202-222.

${ }^{22}$ Valérie Gorin, 'L'enfance comme figure compassionnelle : étude transversale de l'iconographie de la famine aux dix-neuvième et vingtième siècles' in European Review of History: Revue européenne d'histoire, 22:6 (2015), p. 947; Fehrenbach and Rodogno, 'A horrific photo of a drowned Syrian child...', pp. 1136-1137.

${ }^{23}$ Canadian Jewish Review, 5 December 1947, p. 7.

24 'If there's room in your heart', pp. 2-4-6-10.

${ }^{25} \mathrm{Ibid}$. p. 10.

${ }^{26}$ Cohen, Child Survivors of the Holocaust ..., p. 1.

27 'If there's room in your heart', p. 10.

${ }^{28}$ Laura King, 'Future Citizens: Cultural and Political Conceptions of Children in Britain, 1930s-1950s' in Twentieth Century British History, 27, 3 (2016), pp. 389-411; Emily Baughan, 'International Adoption and AngloAmerican Internationalism, c. 1918-1925', Past \& Present, 239, 1, (2018), 181-217; Laura Hilton, 'Who Was "Worthy"? How Empathy Drove Policy Decisions about the Uprooted in Occupied Germany, 1945-1948', Holocaust and Genocide Studies, 32, 1 (2018), 8-28.

${ }^{29}$ Claudia Curio, 'Were Unaccompanied Child Refugees a Privileged Class of Refugees in the Liberal States of Europe?' in Frank Caestecker and Bob Moore (eds.), Refugees from Nazi Germany and the Liberal European States (Oxford: Berghahn Books, 2010), p. 172.

${ }^{30}$ Beside Zahra, see on this issue Verena Buser, 'Displaced Children 1945 and the Child Tracing Division of the United Nations Relief and Rehabilitation Administration', The Holocaust in History and Memory, 7 (2014), pp. 109-123; Lynne Taylor, In the Children's Best Interests: Unaccompanied Children in American-Occupied Germany, 1945-1952 (Toronto: University of Toronto Press, 2017).

${ }^{31}$ Mary Tomsic, "'Happiness again": photographing and narrating the arrival of Hungarian child refugees and their families 1956-1957' in The History of the Family, 22:4 (2017), p. 487.

${ }^{32}$ I am indebted of Annelise Rodrigo's (Université Toulouse II Jean Jaurès) work on pro-refugee campaigns in Montreal during the war years; other examples of such appeals can be found in the section '1937-1946' of the Federation CJA's $100^{\text {th }}$ anniversary website (http://www.federationcja.org/100/decades/1937-1946/ viewed on June 4 2018).

${ }^{33}$ See the AHRC funded project 'Forged by Fire: Burns Injury \& Identity in Britain, c. 1800-2000' led by Jonathan Reinarz, Shane Ewen, and Rebecca Wynter (2016-2020).

${ }^{34}$ CJA, pamphlet 'From Shmad...', May 1948, CJC series FA3 box 1 file 5.

${ }^{35}$ On this issue, see Daniella Doron, Jewish Youth and Identity in Postwar France. Rebuilding Family and Nation (Bloomington: Indiana University Press, 2015).

${ }^{36}$ CJA, pamphlet of the Jewish World Relief Conference (circa 1924).

${ }^{37}$ Canadian Jewish Chronicle (circa 1920).

${ }^{38}$ Christine Charpentier-Boude, La photo de classe. Palimpseste contemporain de l'institution scolaire (Paris: L'Harmattan, 2009).

${ }^{39}$ Heide Fehrenbach, 'Children and Other Civilians: Photography and the Politics of Humanitarian Image-Making' in Fehrenbach and Rodogno, Humanitarian Photography: a history, p. 171.

${ }^{40}$ Gigliotti, 'Displaced children of Europe...', pp. 155-156.

${ }^{41}$ Marta Zarzycka, 'Save the child: photographed faces and affective transactions in NGO child sponsoring programs', European Journal of Women's Studies, 23, 1 (2016), p. 29 cited in Gigliotti, 'Displaced children of Europe, then and now...', p. 160.

${ }^{42}$ Suski, 'Children, Suffering, and the Humanitarian Appeal', p. 213; see also Fehrenbach and Rodogno, “'A horrific photo of a drowned Syrian child"...', p. 1146

${ }^{43}$ Zahra, The Lost Children..., p. 8.

${ }^{44}$ Beth Cohen, 'The last remnant of the Holocaust. The representation and reality of child survivors' lives' in Kate Darian-Smith and Carla Pascoe (eds.), Children, Childhood and Cultural Heritage (Abingdon: Routledge, 2013), p. 94-96.

${ }^{45}$ CJA, minute of meeting, 22 January 1948, Joint Committee of Congress and Welfare Agencies, Montreal, CJC, box 3 1948/36.

${ }^{46}$ Canadian Jewish Review, 5 December 1947, p. 7.

${ }^{47}$ Congress Bulletin, September 1947, p. 2.

${ }^{48}$ Ibid.

49 'If there's room in your heart', p. 6.

${ }^{50}$ Cynthia Comacchio, The Dominion of Youth: Adolescence and the Making of a Modern Canada, 1920 to 1950

(Waterloo: Wilfrid Laurier University Press, 2006), p. 214.

${ }^{51}$ Fehrenbach and Rodogno, “"A horrific photo of a drowned Syrian child”...', p. 1143 
52 Lilie Chouliaraki, 'Post-humanitarianism: Humanitarian communication beyond a politics of pity' in International Journal of Cultural Studies, 13, 2 (2010), p. 112.

${ }^{53} \mathrm{I}$ am indebted to Dr. Maggie Fraser Kirsh that addressed many aspects of this question in her presentation 'Publicity, privacy and protection: the ethics of 'advertising' child survivors' during the Beyond Camps and Forced Labour conference at Birbeck University on January 11 $1^{\text {th }}, 2018$.

${ }^{54}$ See also Mary Fraser Kirsh, 'The Lost Children of Europe: Narrating the Rehabilitation of Child Holocaust Survivors in Great Britain and Israel', PhD dissertation, University of Wisconsin - Madison (2012), pp. $202-206$. ${ }^{55}$ CJA, 'A tribute to a partner in mercy', 1948, UJRA-CJC, box 3 1948 3/47.

${ }^{56}$ Clark, 'Capturing the Moment, Picturing History', p. 831.

57 Peter Novick, The Holocaust in American Life (Boston: Houghton Mifflin Company, 1999); see chapter 3 'Europe's ghosts in Canadian living rooms: the Canadian Jewish Community in the 1950s' of Bialystok, Delayed Impact ..., pp. 68-94.

${ }^{58}$ Hasia R. Diner, We Remember With Reverence and Love: American Jews and the Myth of Silence After the Holocaust, 1945-1962 (New York: New York University Press, 2009); David Cesarani et Eric J. Sundquist, After the Holocaust : Challenging the Myth of Silence, Londres/New York, Routledge, 2012; Eli Lederhendler, 'On Peter Novick's The Holocaust in American Life', Jewish Social Studies, 7, 3 (2001), pp. 159-168.

${ }^{59}$ Lederhendler, 'On Peter Novick...', p. 163.

60 Paragraph 41 of the 'Report of the United Nations High Commissioner for Refugees', (http://www.unhcr.org/excom/unhcrannual/3ae68c930/report-united-nations-high-commissioner-refugees.html).

${ }^{61}$ CJA, 'Canada and the Refugees. An Address by the Honorable Ellen L. Fairclough, Minister of Citizenship and Immigration at the Founder's Day Luncheon of the Hamilton Council of Women', 6 November 1959, CA box 71, file 659, p. 8 .

${ }^{62}$ Maclean's, 10 February 1962, p.12.

${ }^{63}$ Pieter Lagrou, 'Victims of Genocide and National Memory: Belgium, France and the Netherlands 1945-1965' in Past and Present, 154 (1997), p. 195.

${ }^{64}$ Tara Zahra, "AA Human Treasure": Europe's Displaced Children between Nationalism and Internationalism', Past \& Present, 210, 6 (2011), pp. 332-350.

${ }^{65}$ Owen Gingerich, 'The Copernican Quinquecentennial and Its Predecessors: Historical Insights and National Agendas' in Osiris, 14 (1999), p. 37.

${ }^{66}$ Peter Gatrell, Free World?: The Campaign to Save the World's Refugees, 1956-1963 (Cambridge, New York: Cambridge University Press, 2011), pp. 103-104.; Ninette Kelley and Michael Trebilcock, The Making of the Mosaic. A History of Canadian Immigration Policy (Toronto: University of Toronto, 2010 [1998]), pp. 332-333; the World Refugee Year did initiate some early changes in Canada's immigration policy, especially for people with tuberculosis; see chapter 10 'World refugee year: relaxing Canada's Immigration Regulations' of Gerald E. Dirks, Canada's Refugee Policy: Indifference or Opportunism? (Montreal, Kingston: McGill-Queen's University Press, 1977), pp. 214-227.

${ }^{67}$ On the use of tradition of welcome by American, Australian, British, Canadian, Norvegian etc. governments, see Peter Gatrell, 'World Refugee Year, 1959-60 and the History of Population Displacement', 12 January 2011 (https://www.academia.edu/8859604), pp. 4-5.

${ }^{68}$ Gatrell, Free World..., p. 135.

${ }^{69}$ Lappin, The Redeemed Children..., p. viii.

${ }^{70}$ Maclean's, 10 February 1962, p.13.

71 Liisa H. Malkki, 'Speechless emissaries: refugees, humanitarian and dehistoricization' in Cultural Anthropology, 11, 3 (1996), pp. 377-404.

${ }^{72}$ There was one notable exception when Jack Kuper, an orphan that came to Canada through the CJC project, published a book in 1967. He became one of the first voices among the 'pioneering works' in the genre of child survivors' published memoirs; Jack Kuper, Child of the Holocaust (London: Routledge and Keegan Paul, 1967); see Martin Ira Glassner and Robert Krell, And Life is Changed Forever: Holocaust Childhoods Remembered (Detroit: Wayne State University Press, 2006), p. 7.

${ }^{73}$ Canadian Jewish Congress, Fifty years of service, 1919-1969 (Montreal: CJC, 1969), p. 40.

${ }^{74}$ For a better understanding of the complicated debates around the development of an 'Holocaust consciousness', see the works of Novick, Bialystok, Lederhendler, and Diner (notes 53 and 54).

${ }^{75}$ Annette Wieviorka, The Era of the Witness (Ithaca: Cornell University Press, 2006 [1998])

${ }^{76}$ Janice Rosen, 'Holocaust Testimonies and Related Resources in Canadian Archival Repositories' in Canadian Jewish Studies/Études Juives Canadiennes, 4-5 (1997), pp. 163-175.

${ }^{77}$ See for instance Howar Chandler (Holocaust Documentation Project)

${ }^{78}$ Anna Sheftel and Stacey Zembrzycki, 'We started over again, we were young: postwar social worlds of child Holocaust survivors in Montreal' in Urban History Review/Revue d'Histoire Urbaine, 39, 1 (2010), pp. 20-30.

${ }^{79}$ Lappin, The Redeemed Children..., p. 100.

${ }^{80}$ I would like to thank Dr. Rebecca Clifford for pointing this out to me. 


\footnotetext{
${ }^{81}$ See note 2 in this article.

${ }^{82}$ See www.virtualmuseum.ca (viewed on 4 June 2018)

${ }^{83}$ Vancouver Holocaust Education Centre, 'Open Hearts - Closed Doors: The War Orphans Project. Teacher's Guide Addendum' (Vancouver: VHEC, 2016), p. 2.

${ }^{84}$ See for instance Jessica Murphy, 'Jewish war orphans reunite in Montreal', The Star, 27 October 2008 (https://www.thestar.com/news/canada/2008/10/27/jewish_war_orphans_reunite_in_montreal.html viewed on 4 June 2018); Renée Ghert-Zand, 'Holocaust survivor helps Canada's kidnapped aboriginals heal', The Times of Israel, 17 December 2015 (https://www.timesofisrael.com/holocaust-survivor-helps-canadas-kidnappedaboriginals-heal/ viewed on 4 June 2018); Michelle Cheung, 'Holocaust survivors call on world to indict those responsible for Syrian atrocities', CBC News, 21 December 2016 (http://www.cbc.ca/news/canada/toronto/holocaust-syria-war-crimes-1.3907326 viewed on 4 June 2018); Michael Fraiman, 'A fresh start: The story of Canada's postwar Jewish orphans', The Canadian Jewish News, 28 March 2018 (http://www.cjnews.com/perspectives/features/the-story-of-1123-orphans-who-came-to-canada-after-theholocaust viewed on 4 June 2018).

${ }^{85}$ Cohen, 'The last remnant of the Holocaust...', 175 .

${ }^{86}$ See the entrees 'Residential schools' and 'British Home children' on The Canadian Encyclopedia (http://www.thecanadianencyclopedia.ca/en/article/residential-schools/ viewed on 4 June 2018).

${ }^{87}$ Stephanie Bangarth, 'Canada's Complicated History of Refugee Reception', Activehistory.ca, 4 September 2015 (http://activehistory.ca/2015/09/canadas-complicated-history-of-refugee-reception/ viewed on 4 June 2018).

${ }^{88}$ See the project's website (http://www.montrealenhistoires.com/en/cite-memoire/ viewed on 4 June 2018).

${ }^{89}$ Janice Arnold, 'Exhibit Pays Tribute to Orphaned Survivors Rescued by Jewish Montrealers', The Canadian Jewish News, 8 June 2016 (http://www.cjnews.com/news/canada/montreal-exhibit-honours-orphaned-holocaustsurvivors viewed on 4 June 2018).

90 Susan Schwartz, 'Cité Mémoire makes history in Old Montreal', Montreal Gazette, 3 June 2016 (http://montrealgazette.com/entertainment/arts/cite-memoire-makes-history-in-old-montreal viewed on 1 September 2018).

${ }^{91}$ Fehrenbach, 'Children and Other Civilians...', p. 171.

${ }^{92}$ On the interwar activities of the International Red Cross Committee, Francesca Piana, 'Photography, Cinema, and the Quest for Influence' in Fehrenbach and Rodogno, Humanitarian Photography, pp. 140-164.; on the AJDC, see Eric Nooter, 'Displaced Persons from Bergen-Belsen. The JDC Photographic Archives' in History of Photography, 23, 4 (1999), pp. 331-340.

${ }^{93}$ King, 'Future Citizens...', p. 392.

${ }^{94}$ Harry Hendrick, Children, Childhood and English Society, 1880-1990 (Cambridge: Cambridge University Press, 1997), p. 3.

${ }^{95}$ Gigliotti, 'Displaced children of Europe...', p. 170.

${ }^{96}$ See on this controversial issue, Irving Abella and Harold Troper, None is too many: Canada and the Jews of Europe, 1933-1948 (Toronto: Lester, 1991 [1982]); for a recent discussion on Abella and Troper's work, see the contributions in Antoine Burgard and Rebecca Margolis (eds.), 'None Is Too Many and Beyond: New Research on Canada and the Jews During the 1930-1940s', Canadian Jewish Studies/ Études Juives Canadiennes, 24 (2016)

97 Andrew Lui, Why Canada Cares: Human Rights and Foreign Policy in Theory and Practice (Montreal, Kingston: McGill-Queen's University Press, 2012), p. 3.

${ }^{98}$ Malkki, 'Speechless Emissaries...', p. 377.
} 







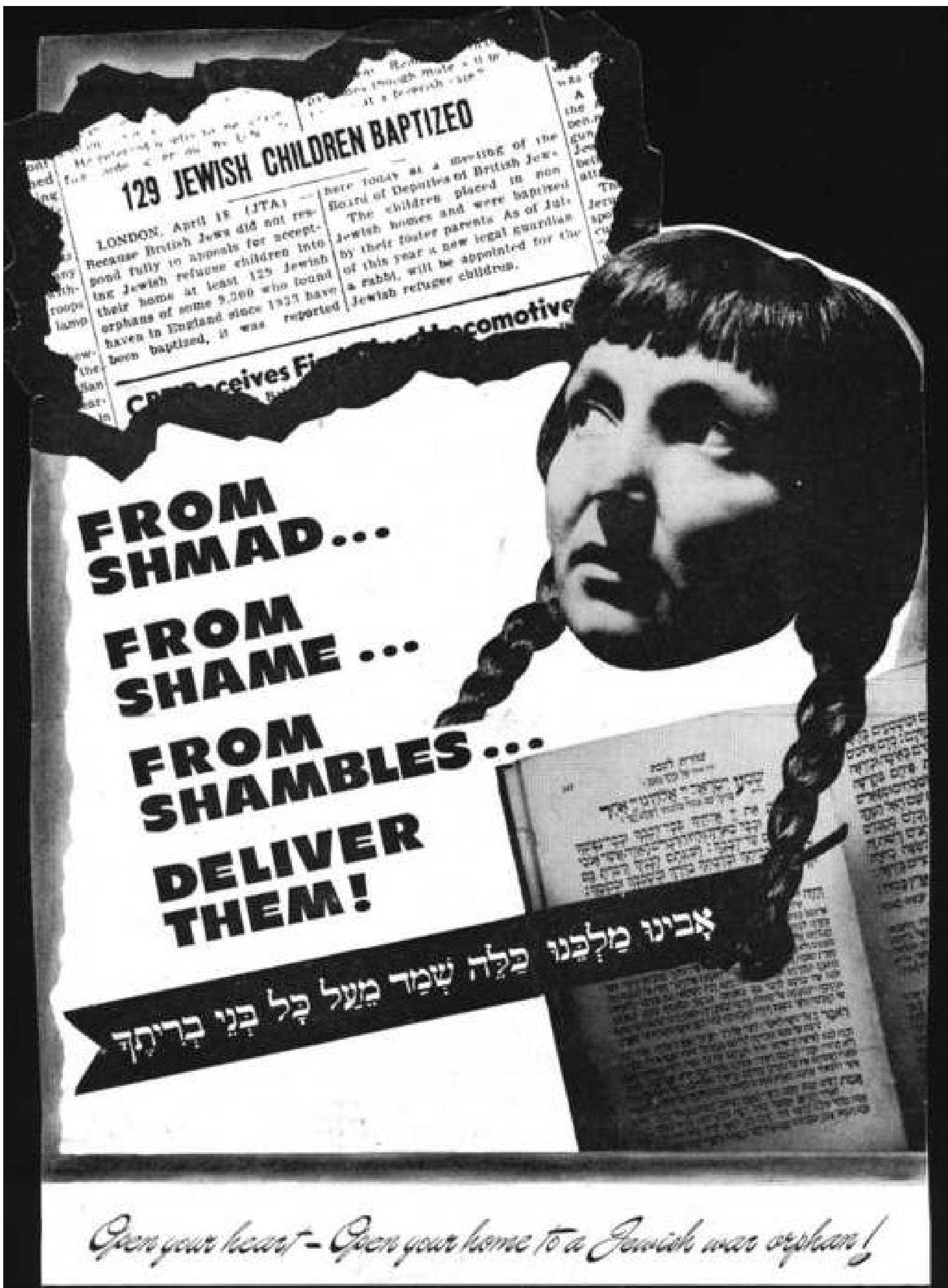

CANADIAN IEWISH CONGRESS WAR ORPHANS PROIECT 


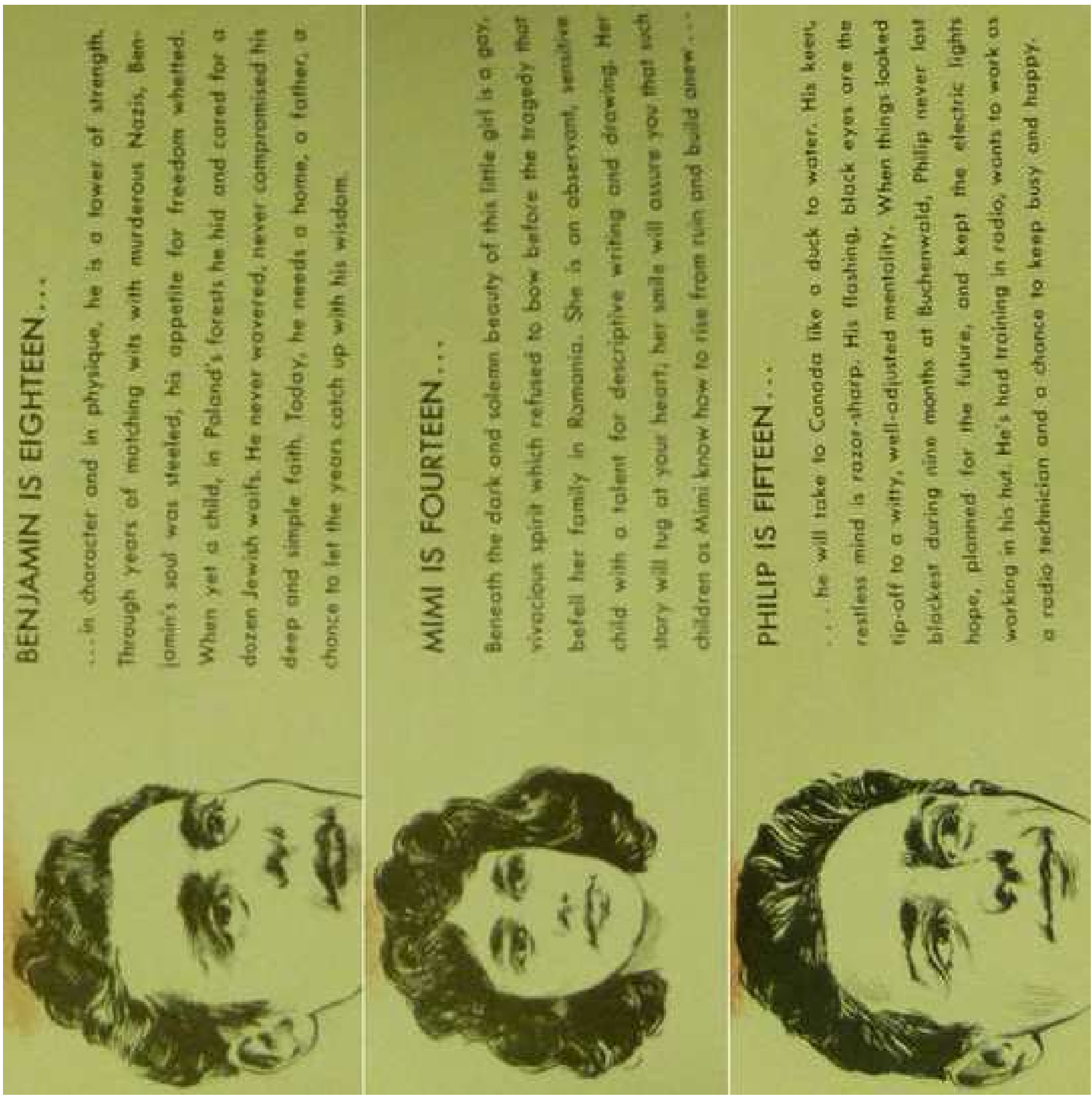




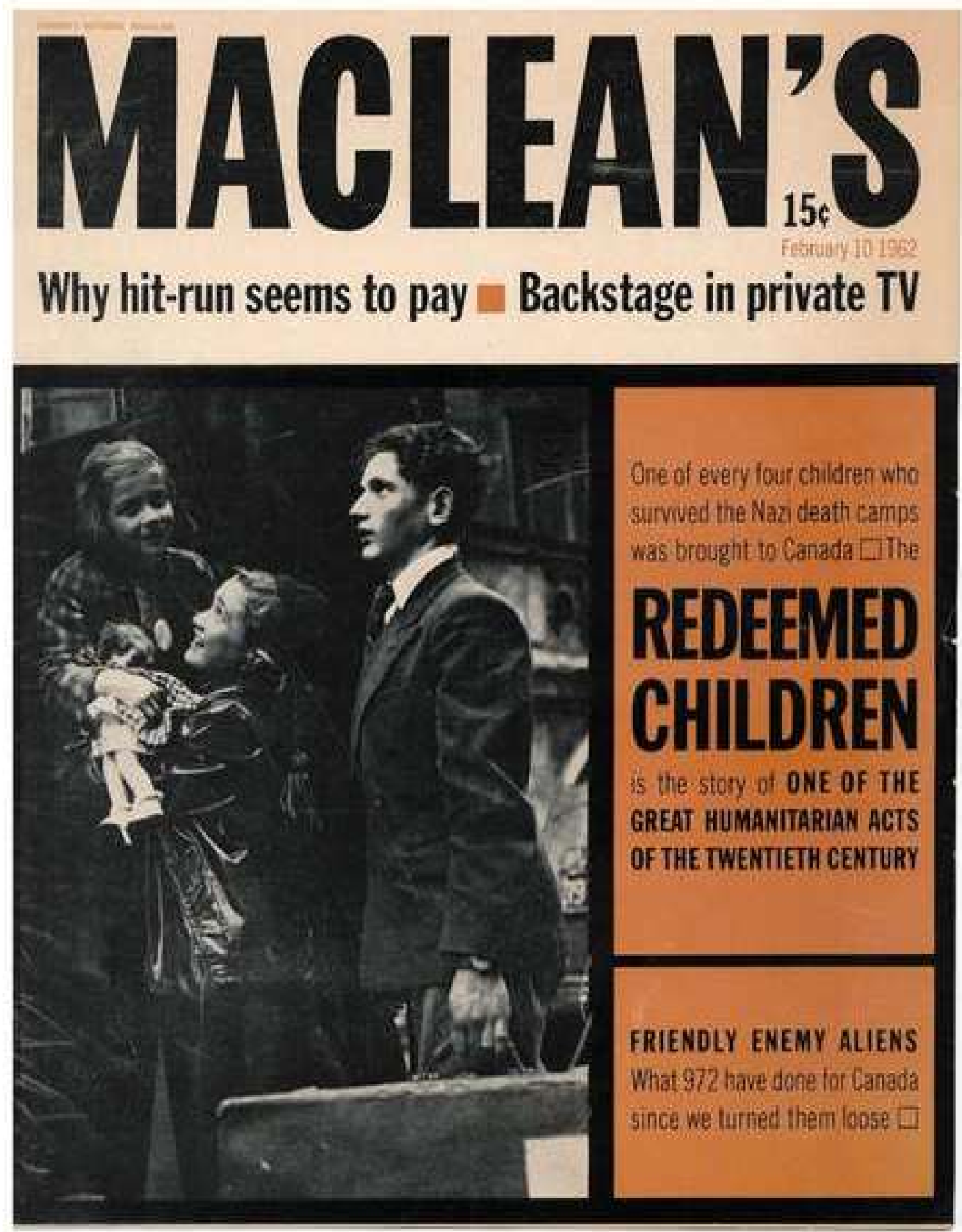



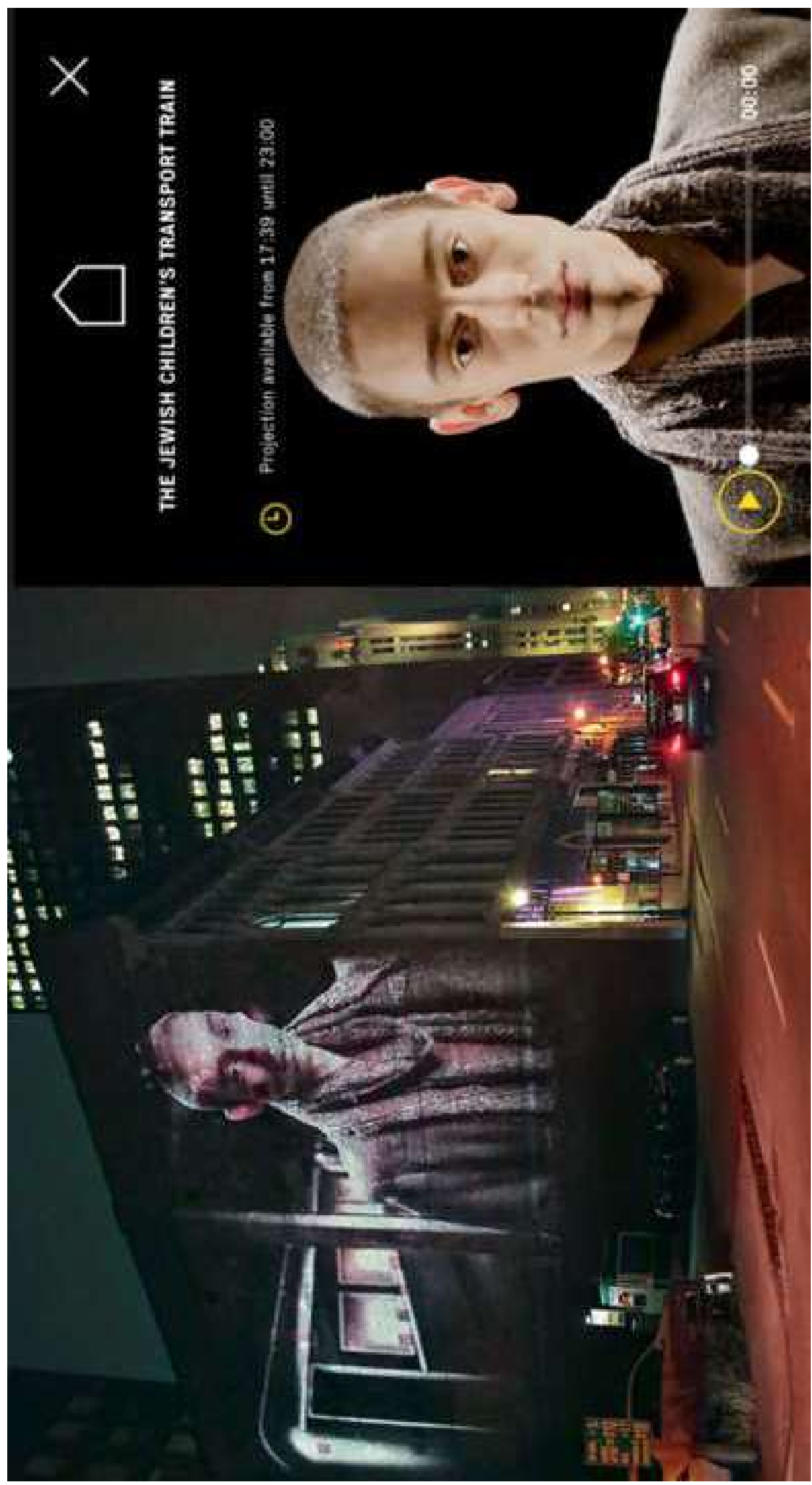